\title{
ZAGROŻENIA NATURALNE I TECHNICZNE WPLYWAJĄCE NA STAN BEZPIECZEŃSTWA PRACY W POLSKICH KOPALNIACH ODKRYWKOWYCH
}

\begin{abstract}
Górnictwo odkrywkowe jest najstarszym sposobem wydobywania kopalin użytecznych, które wykorzystywane są przez człowieka od tysięcy lat. W dzisiejszych czasach eksploatacja odkrywkowa jest podstawową gałęzią gospodarek wielu krajów, w tym również krajów wysoko rozwiniętych. Pozwala pozyskiwać surowce energetyczne, metaliczne, chemiczne i skalne. W Polsce w ostatnich latach obserwowany jest dynamiczny rozwój branży górnictwa odkrywkowego. W ostatnich 15 latach nastąpiło podwojenie liczby odkrywkowych zakładów górniczych.

Od początku istnienia górnictwa, praca górników związana była z licznymi niebezpieczeństwami, które zagrażały ich życiu i zdrowiu. Do podstawowych zagrożeń wpływających na stan bezpieczeństwa pracy w kopalniach odkrywkowych należą zagrożenia naturalne o charakterze geologicznym, geotechnicznym i hydrogeologicznym oraz zagrożenia o charakterze technicznym związane z zastosowaniem określonych technologii wydobycia i przerobu surowca, maszyn, urządzeń i środków transportu.

W artykule przedstawiono definicję kopalni odkrywkowej, podział kopalń ze względu na przeznaczenie gospodarcze kopalin oraz stan zatrudnienia w kopalniach. Opisano podstawowe zagrożenia występujące na stanowiskach pracy w górnictwie odkrywkowym. Na podstawie danych Wyższego Urzędu Górniczego dotyczących sektora górnictwa odkrywkowego, przeprowadzono analizę wypadków, ze szczególnym uwzględnieniem zdarzeń związanych z zagrożeniami naturalnymi i technicznymi. Scharakteryzowano i opisano skalę występujących zagrożeń osuwiskowych, wywołanych obrywaniem się skał, wodnych, sejsmicznych, gazowych, wywołanych pożarami endogenicznymi oraz technicznych związanych ze stosowaniem środków strzałowych i pochodzących od maszyn i urządzeń.
\end{abstract}

Słowa kluczowe: zagrożenia naturalne, zagrożenia techniczne, górnictwo odkrywkowe, bezpieczeństwo pracy w górnictwie.

1 Dr inż. Romuald Ogrodnik, Katedra Ekonomiki i Zarządzania w Przemyśle, Wydział Górnictwa i Geoinżynierii, AGH Akademia Górniczo-Hutnicza, al. Mickiewicza 30, 30-059 Kraków; e-mail: rogrod@agh.edu.pl; tel. 126172309 (autor korespondencyjny).

2 Dr hab. inż. Zbigniew Burtan, Katedra Górnictwa Podziemnego, Wydział Górnictwa i Geoinżynierii, AGH Akademia Górniczo-Hutnicza, al. Mickiewicza 30, 30-059 Kraków; e-mail: burtan@agh.edu.pl; tel. 126174930.

3 Dr inż. Mariusz Kapusta, Katedra Górnictwa Podziemnego, Wydział Górnictwa i Geoinżynierii, AGH Akademia Górniczo-Hutnicza, al. Mickiewicza 30, 30-059 Kraków; e-mail: kapustam@agh.edu.pl'tel. 126172164. 


\section{WPROWADZENIE}

Górnictwo to specyficzny rodzaj działalności związany z niespotykanymi w innych gałęziach przemysłu zagrożeniami, które mogą powodować szkody i straty, a w szczególności wypadki, urazy i choroby pracowników. Występowanie poszczególnych zagrożeń naturalnych uzależnione jest między innymi od sposobów eksploatacji złóż. W górnictwie odkrywkowym występują zagrożenia naturalne o zupełnie innym charakterze niż w górnictwie podziemnym czy górnictwie otworowym. Zagrożenia techniczne mogą być uwarunkowane rodzajami maszyn i urządzeń wykorzystywanych przy danym sposobie eksploatacji oraz uzależnione od konieczności wykorzystania materiałów wybuchowych.

Zgodnie z obowiązującym Prawem geologicznym i górniczym przedsiębiorca jest obowiązany rozpoznawać zagrożenia związane $\mathrm{z}$ ruchem zakładu górniczego i podejmować środki zmierzające do zapobiegania i usuwania tych zagrożeń ${ }^{4}$.

Na potrzeby artykułu dokonano identyfikacji wybranych danych, pochodzących z corocznych raportów dotyczących stanu bezpieczeństwa pracy, ratownictwa górniczego oraz bezpieczeństwa powszechnego w związku z działalnością górniczo-geologiczną oraz raportów dotyczących stanu bezpieczeństwa i higieny pracy w górnictwie, publikowanych przez Wyższy Urząd Górniczy. Wykorzystane dane dotyczyły m.in. liczby i rodzaju wypadków, kształtowania się wskaźników częstotliwości i ciężkości wypadków, przyczyn, które doprowadziły do powstania wypadków oraz stanu zatrudnienia w kopalniach odkrywkowych.

\section{PODZIAŁ KOPALŃ ODKRYWKOWYCH, ICH LICZBA ORAZ STAN ZATRUDNIENIA}

Górnictwo odkrywkowe to dynamicznie rozwijająca się część branży górniczej, zajmująca dominującą pozycję w ogólnym bilansie wydobywczym kraju.

Pod pojęciem kopalni odkrywkowej należy rozumieć zakład górniczy, w którym eksploatacja złoża polega na usunięciu przykrycia skalnego zalegającego nad kopaliną oraz na wybieraniu odsłoniętego w ten sposób złoża w otwartym wyrobisku.

W literaturze przedmiotu występuje wiele kryteriów podziału kopalń odkrywkowych, m.in. ze względu na wielkość wydobycia, na wysokość bezwzględną ich położenia czy też ze względu na głębokość prowadzonej eksploatacji. Według Prawa geologicznego i górniczego kopaliny można podzielić na kopaliny objęte własnością górniczą oraz objęte prawem własności nieruchomości gruntowej ${ }^{5}$. Wykorzystując dodatkowo informacje dotyczące przeznaczenia gospodarczego poszczególnych kopalin można uzyskać następujący podział:

- górnictwo odkrywkowe kopalin objętych własnością górniczą:

- kopalnie węgla brunatnego;

- kopalnia siarki (w likwidacji)

- pozostałe:

- górnictwo odkrywkowe kopalin objętych prawem własności nieruchomości gruntowej:

\footnotetext{
4 Ustawa z dnia 9 czerwca 2011 r. Prawo geologiczne i górnicze (tekst jedn. Dz.U. z 2016 r., poz. 1131).

5 Tamże.
} 
- kopalnie wydobywające kruszywa naturalne piaszczysto-żwirowe i piaski żwirowe (do produkcji betonów komórkowych i cegły wapienno-piaskowej) oraz piaski podsadzkowe;

- kopalnie kamieni drogowych i budowlanych;

- kopalnie prowadzące eksploatację złóż surowców ilastych (na potrzeby ceramiki budowlanej);

- pozostałe (m.in. torfu, kredy jeziornej).

Według stanu na dzień 31.12.2016 r., na terenie Polski urzędy górnicze sprawowały nadzór i kontrolę nad ruchem 7298 odkrywkowych zakładów górniczych (rys. 1), z czego 16 zakładów wydobywało kopaliny objęte własnością górniczą, a 7282 kopaliny objęte prawem własności nieruchomości gruntowej (rys. 2).

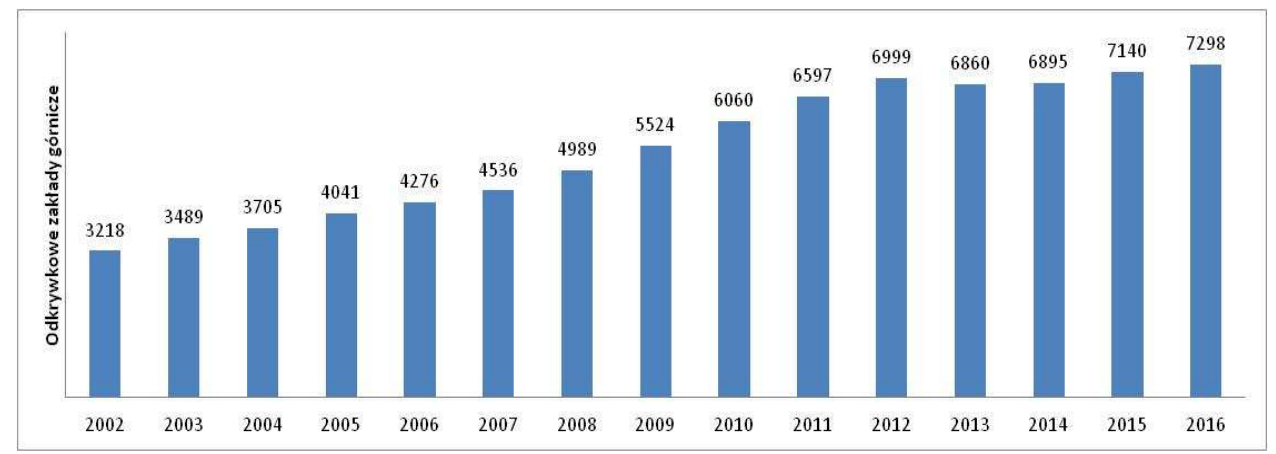

Rys. 1. Zakłady odkrywkowe objęte nadzorem urzędów górniczych w latach 2002-2016

Źródło: opracowanie własne na podstawie danych WUG (2003-2016).

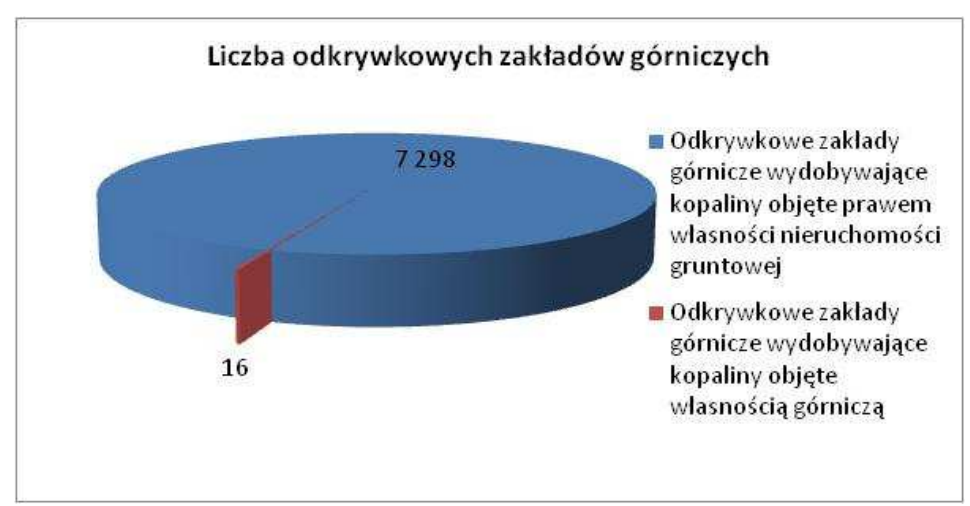

Rys. 2. Liczba odkrywkowych zakładów górniczych - stan na 31.12.2016 r.

Źródło: opracowanie własne na podstawie: Ocena stanu bezpieczeństwa pracy, ratownictwa górniczego oraz bezpieczeństwa powszechnego w związku z działalnością górniczo-geologiczną w 2016 roku, WUG, Katowice 2016. 
W 2015 roku 23\% zatrudnionych pracowników kopalń odkrywkowych pracowało w zakładach eksploatujących kopaliny objęte prawem własności górniczej (rys. 3), z czego blisko 99\% stanowili pracownicy kopalń węgla brunatnego.

W latach 2002-2015 otwarto blisko 4 tys. nowych odkrywkowych zakładów górniczych. W tym okresie liczba kopalń węgla brunatnego utrzymywała się na podobnym poziomie, w 2002 r. funkcjonowało 11 kopalń, obecnie jest ich 12. W omawianym okresie pomimo znaczącego wzrostu liczby funkcjonujących odkrywkowych zakładów górniczych, wystąpił spadek zatrudnienia w całym górnictwie odkrywkowym, z 35763 w 2002 r. do 28129 osób w 2015 r. Jest to spowodowane restrukturyzacją zatrudnienia w kopalniach węgla brunatnego, w wyniku której w analizowanym okresie zmniejszono zatrudnienie blisko 4-krotnie, z 25248 zatrudnionych w 2002 r. do 6351 w 2015 r.

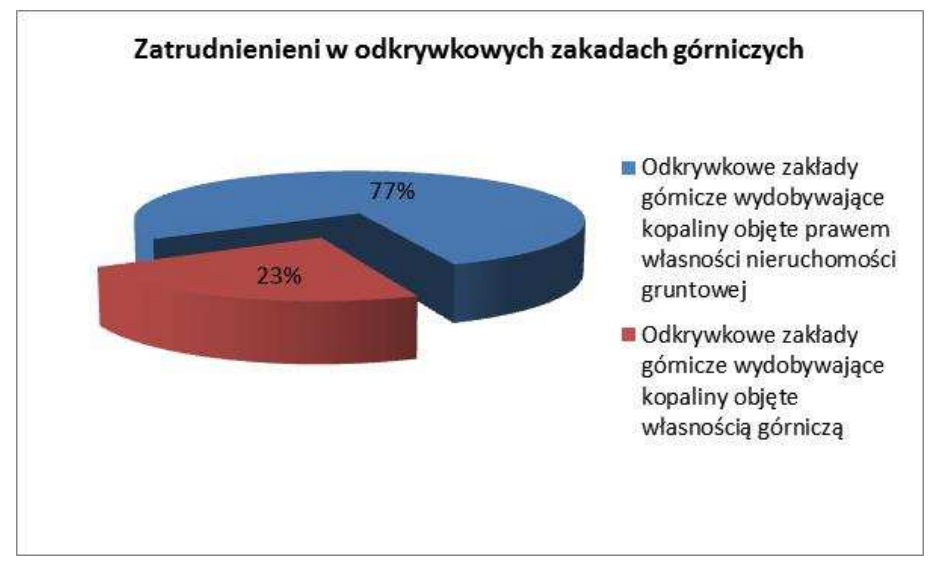

Rys. 3. Procentowy udział zatrudnionych w kopalniach eksploatujących poszczególne kopaliny - stan na 31.12.2015 r.

Źródło: opracowanie własne na podstawie: Ocena stanu bezpieczeństwa pracy, ratownictwa górniczego oraz bezpieczeństwa powszechnego w zwiazku z działalnościa górniczo-geologiczna w 2016 roku...

\section{ZAGROŻENIA W GÓRNICTWIE ODKRYWKOWYM}

Zagrożenie definiowane jest jako zjawisko wywołane działaniem sił natury bądź człowieka, które powoduje, że poczucie bezpieczeństwa maleje bądź zupełnie zanika. Zagrożenie może powodować szkody lub straty, a w szczególności wypadek lub chorobę 6 . Do zagrożeń występujących w miejscu pracy należą: zagrożenia naturalne, techniczne, osobowe i organizacyjne.

Podczas eksploatacji kopalin, górnikom od wieków towarzyszyły liczne zagrożenia oddziałujące na ich zdrowie i życie, jak również wpływające na funkcjonowanie całych kopalń. Do podstawowych zagrożeń wpływających na stan bezpieczeństwa pracy w kopalniach odkrywkowych należą zagrożenia naturalne o charakterze geologicznym, geotech-

6 J. Szlązak, N. Szlązak, Bezpieczeństwo i higiena pracy, Kraków 2005. 
nicznym i hydrogeologicznym oraz zagrożenia o charakterze technicznym związane z zastosowaniem określonych technologii wydobycia i przerobu surowca, maszyn, urządzeń i środków transportu.

\subsection{Zagrożenia naturalne}

Do podstawowych zagrożeń występujących w górnictwie odkrywkowym należy zaliczyć zagrożenia ${ }^{7}$ :

- osuwiskowe i wywołane obrywaniem się skał;

- wodne;

- sejsmiczne;

- gazowe;

- pożarami endogenicznymi;

- inne związane z budową geologiczną złoża i nadkładu (np. występowanie warstw trudno urabialnych, duża zmienność zalegania urabianych warstw, zjawiska krasowe, występowanie głazów narzutowych lub pni dębów).

\section{Zagrożenia osuwiskowe i wywołane obrywaniem się skał}

Osuwisko definiowane jest jako przemieszczenie się, w wyniku naruszenia stanu równowagi w górotworze, mas skalnych budujących skarpę lub zbocze, stwarzające niebezpieczeństwo dla pracowników lub ruchu zakładu górniczego ${ }^{8}$.

W odkrywkowych zakładach górniczych ustalono dwa stopnie zagrożenia osuwiskowego. Przy ustaleniu stopnia zagrożenia osuwiskowego służba geologiczna ocenia następujące okoliczności mogące wystąpić w skarpie, zboczu złoża (lub jego części), wyrobisku (lub jego części) lub zwałowisku9 :

- warstwy nachylone w stronę wyrobiska, a spękania umożliwiające odspajanie się większych mas skalnych są ułożone równolegle do skarpy;

- przewarstwienia skał o różnych parametrach wytrzymałościowych i właściwościach geomechanicznych, przewarstwienia skał wodonośnych lub powierzchnie podzielności ławicowej;

- strefy wietrzeniowe lub strefy zmian hydrotermalnych, w szczególności żyły kruchych minerałów, zailenie, serycytyzacja lub chlorytyzacja;

- uskoki;

- brekcje tektoniczne;

- spękania ciosowe;

- strefy drgań spowodowanych ruchem pojazdów, wstrząsy wywołane robotami strzałowymi lub ruchem maszyn lub urządzeń, mogące wpływać na możliwość utraty stateczności skarp lub zboczy;

- inne okoliczności mogące spowodować utratę stateczności skarp lub zboczy w stopniu stwarzającym niebezpieczeństwo dla pracowników lub ruchu zakładu górniczego.

\footnotetext{
7 Zagrożenia naturalne w odkrywkowych zakładach górniczych, Wyższy Urząd Górniczy, Katowice 2007.

8 Rozporządzenie Ministra Środowiska z dnia 29 stycznia 2013 r. w sprawie zagrożeń naturalnych w zakładach górniczych (tekst jedn. Dz.U. z 2015 r., poz. 1702).

9 Tamże.
} 
Zagrożenie związane z oberwaniem się skał związane jest $\mathrm{z}$ powstaniem nawisów skalnych, spękań czy szczelin w wyniku stosowania w zakładach odkrywkowych materiałów wybuchowych. Kluczowa jest również budowa geologiczna danego złoża (sposób zalegania złoża, zjawiska krasowe, tektonika) oraz sposoby jego eksploatacji.

Zagrożenie osuwiskowe występuje głównie w kopalniach węgla brunatnego i kopalniach eksploatujących surowce ilaste natomiast zagrożenia związane z obrywaniem się skał ze ścian eksploatacyjnych w kopalniach odkrywkowych surowców skalnych.

W kopalniach odkrywkowych w latach 1990-2016 zaistniało 29 zdarzeń związanych z zagrożeniem osuwiskowym, w wyniku których zginął jeden górnik. W omawianym okresie wystąpiło 13 zdarzeń związanych z zagrożeniem oberwania się skał, w wyniku których zginęło 4 górników, 4 doznało ciężkich urazów, a 7 urazów lekkich. Liczbę zdarzeń związanych z zagrożeniami osuwiskowymi oraz wywołanymi obrywaniem się skał w latach 1990-2016 obrazuje rys. 4. Na uwagę zasługuję fakt, iż w ostatnich pięciu latach wystąpiły tylko dwa zdarzenia związane z omawianymi zagrożeniami, które nie spowodowały żadnych wypadków przy pracy.

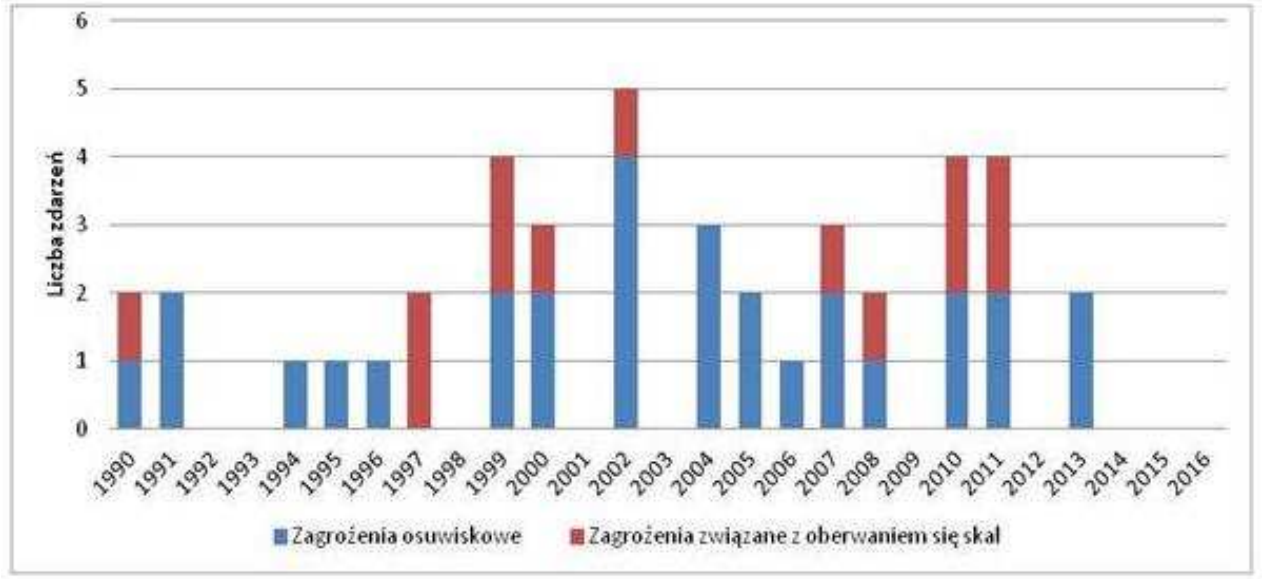

Rys. 4. Zdarzenia związane z zagrożeniem osuwiskowym i obrywaniem się skał w latach 1990-2016 Źródło: opracowanie własne na podstawie: Zagrożenia naturalne w odkrywkowych zakładach górniczych, WUG, Katowice 2007 oraz danych WUG (2003-2016)

\section{Zagrożenie wodne}

Zagrożenie wodne to możliwość wystąpienia zwiększonego lub niekontrolowanego dopływu albo możliwość wdarcia się do istniejącego lub projektowanego wyrobiska lub jego części: wody, solanki, ługów lub wody z luźnym materiałem, stwarzającego niebezpieczeństwo dla pracowników lub ruchu zakładu górniczego ${ }^{10}$.

Dla odkrywkowych zakładów górniczych ustalono dwa stopnie zagrożenia wodnego. Do I stopnia zagrożenia wodnego zalicza się złoże lub jego część, jeżeli jest możliwe ${ }^{11}$ :

\footnotetext{
${ }^{10}$ Tamże.

${ }^{11}$ Tamże.
} 
1) zatopienie wyrobiska odkrywkowego lub jego części w przypadku zaistnienia gwałtownych opadów atmosferycznych lub

2) bezpośrednie wdarcie się wody ze zbiorników lub cieków wodnych znajdujących się na powierzchni terenu do wyrobiska odkrywkowego, lub

3) wypłynięcie wody ze skarp lub spągu wyrobiska odkrywkowego w ilości stwarzającej niebezpieczeństwo dla pracowników lub ruchu zakładu górniczego.

Do II stopnia zagrożenia wodnego zalicza się złoże lub jego część, jeżeli w tej przestrzeni zaistniały wyżej wymienione okoliczności.

Analizując okres ostatnich 25 lat można stwierdzić, iż zdarzenia powodujące zagrożenia wodne w polskich kopalniach odkrywkowych wystąpiły przede wszystkim w związku $\mathrm{z}$ intensywnymi opadami atmosferycznymi oraz falą powodziową. $\mathrm{W}$ omawianym okresie nie odnotowano wypadków przy pracy bezpośrednio związanych z wdarciem się wody do wyrobisk zakładów górniczych. W 2010 roku, w wyniku intensywnych i długotrwałych opadów atmosferycznych częściowo zalanych zostało 164 kopalni odkrywkowych.

\section{Zagrożenie sejsmiczne}

Zagrożenie sejsmiczne występuje w Kopalni Węgla Brunatnego „Bełchatów”. Zjawisko to jest związane z lokalną budową geologiczną złoża i jego tektoniką. Młoda struktura tektoniczna charakteryzująca się występowaniem nie do końca zrelaksowanych naprężeń tektonicznych uaktywnia się w wyniku eksploatacji pokładów węgla brunatnego oraz systematycznego odwadniania górotworu ${ }^{12}$.

W latach 1990-2016 zarejestrowano ponad 750 wstrząsów o energii poniżej $10^{8} \mathrm{~J}$ oraz 16 wstrząsów o energii powyżej $10^{8} \mathrm{~J}$, które nie spowodowały zagrożenia bezpieczeństwa ludzi, ruchu zakładu górniczego ani uszkodzeń maszyn i urządzeń. Wstrząsy o dużej energii mogą powodować uszkodzenia sąsiadujących z kopalnią obiektów budowlanych.

\section{Zagrożenie gazowe}

Zagrożenie gazowe może powstać w kopalniach węgla brunatnego przy wierceniu otworów badawczych lub studni odwadniających oraz w czasie ich eksploatacji. W analizowanych raportach Wyższego Urzędu Górniczego nie znaleziono potwierdzonych informacji dotyczących zdarzeń związanych z występowaniem zagrożeń gazowych w polskich kopalniach odkrywkowych. Warto odnotować występowanie zagrożenia siarkowodorowego w likwidowanej Kopalni Siarki „Machów” występujące w czasie pracy zewnętrznej zachodniej bariery studni odwadniających utrzymującej się na ustalonym bezpiecznym poziomie stanu wód w wyrobisku poeksploatacyjnym nieczynnej Kopalni Siarki „Piaseczno" 13

\section{Zagrożenie pożarami endogenicznymi}

Zagrożenie pożarami endogenicznymi w górnictwie odkrywkowym występuje w kopalniach węgla brunatnego na stałych, długo odsłoniętych skarpach i zboczach, zawierających wkładki węgla, rzadziej na poziomach węglowych oraz w kopalniach torfu ${ }^{14}$.

\footnotetext{
12 Zagrożenia naturalne... .

13 Ocena stanu bezpieczeństwa pracy, ratownictwa górniczego oraz bezpieczeństwa powszechnego w zwiazku z działalnością górniczo-geologiczna w 2015 roku, WUG, Katowice 2016.

${ }^{14}$ Zagrożenia naturalne...
} 
W latach 1990-2016 zarejestrowano dwa przypadki powstania pożarów endogennych na terenach górniczych zakładów odkrywkowych. W 2005 roku, w centralnej części zakładu górniczego „Józefowo” wystąpił pożar torfu składowanego na złożu. Pożar objął powierzchnię ok. 2,5 ha, spaleniu uległo około 2,5 tys. $\mathrm{m}^{3}$ torfu cegiełkowego i około 1000 $\mathrm{m}^{3}$ torfu frezowego. W 2011 roku na terenie KWB „Turów” wystąpiło samozapalenie się węgla brunatnego $\mathrm{w}$ zlikwidowanym podziemnym chodniku wodnym. W wyniku omawianego zdarzenia, zanotowano 1 wypadek lekki - zatrucie tlenkiem węgla.

\subsection{Zagrożenia techniczne}

Niezależnie od występujących zagrożeń naturalnych, istotny wpływ na stan bezpieczeństwa w odkrywkowych zakładach górniczych mają zagrożenia techniczne.

Zagrożenia techniczne to energia, związki lub preparaty chemiczne związane z procesem technologicznym, które mogą oddziaływać na organizm ludzki. Niebezpieczny kontakt pracowników z obiektami, energią i substancjami przestrzeni roboczej może prowadzić do wypadku, którego efektem może być uszczerbek na zdrowiu lub śmierć15.

Do podstawowych zagrożeń technicznych występujących w odkrywkowych zakładach górniczych należą zagrożenia związane ze stosowaniem środków strzałowych, zagrożenia od maszyn i urządzeń oraz zagrożenia pożarowe.

\section{Zagrożenia związane ze stosowaniem środków strzałowych}

Zagrożenia związane ze stosowaniem środków strzałowych występują w kopalniach odkrywkowych, w których eksploatuje się zwięzłe surowce skalne oraz w kopalniach posiadających trudno ubieralne warstwy nadkładu. Zagrożenie to związane jest z używaniem materiałów wybuchowych i środków inicjujących, które ze względu na ich skład chemiczny lub konstrukcję odznaczają się potencjalnym niebezpieczeństwem wybuchu. Zagrożenie to może powstać przy wszystkich czynnościach związanych z używaniem środków strzałowych: przewozem, przechowywaniem, wydawaniem, przenoszeniem oraz stosowaniem środków strzałowych.

Najczęstsze przyczyny zaistniałych zdarzeń mają związek z nawiercaniem środka strzałowego w otworze strzałowym, nie wycofaniem pracowników do miejsc bezpiecznych, brakiem obstawy dojść do miejsca wykonywania robót strzałowych oraz użyciem zapalarki do kontroli obwodu strzałowego ${ }^{16}$.

W latach 2000-2016 wystąpiło 8 zdarzeń związanych ze stosowaniem środków strzałowych, w wyniku których 1 pracownik poniósł śmierć, 1 doznał obrażeń ciężkich i 3 obrażeń lekkich. W 2010 roku operator koparki został ranny odłamkami skalnymi, powstałymi w wyniku detonacji ładunku materiału wybuchowego (niewypału) podczas nabierania urobku do łyżki koparki.

W 2013 roku dynamicznie przemieszczające się odłamki skalne po wybuchu nawierconych środków strzałowych, uderzyły pracownika P.P.U. „Czernica-Granit”. Najtragiczniejszy wypadek miał miejsce w 2001 roku w Kopalni Wapienia „Morawica”, gdzie podczas wiercenia otworów, nastąpiła detonacja materiałów wybuchowych, w wyniku której

15 E. Ciechowski, A. Szczurowski, Seminarium z bezpieczeństwa i higieny pracy w górnictwie, Gliwice 1996

16 Stan bezpieczeństwa i higieny pracy w górnictwie w 2002, ... 2012 roku, WUG, Katowice 2003, ... 2013. 
odłamki skalne śmiertelnie raniły jednego z pracowników, a dwóch pozostałych doznało lżejszych obrażeń.

\section{Zagrożenia techniczne od maszyn i urządzeń}

W latach 2000-2016 w wyniku niewłaściwej eksploatacji maszyn i urządzeń doszło do 19 wypadków śmiertelnych i 18 wypadków ciężkich. W analizowanym okresie wystąpiło 37 zdarzeń spowodowanych omawianymi zagrożeniami. Przyczyną większości wypadków było przebywanie poszkodowanych w strefach niebezpiecznych podczas pracy maszyn i urządzeń oraz nieprzestrzeganie zaleceń zawartych w dokumentacjach techniczno-ruchowych oraz regulaminach ruchu pojazdów. Udział wypadków związany z użytkowaniem poszczególnych grup maszyn i urządzeń przedstawia rysunek 5.

W analizowanym okresie 8 wypadków bezpośrednio związanych było z wykonywaniem prac przy przenośnikach taśmowych będących w ruchu, 6 wypadków związanych było z eksploatacją pojazdów, 4 - z wykonywaniem prac pomocniczych i remontowych oraz 19 związanych było z eksploatacją innych maszyn i urządzeń.

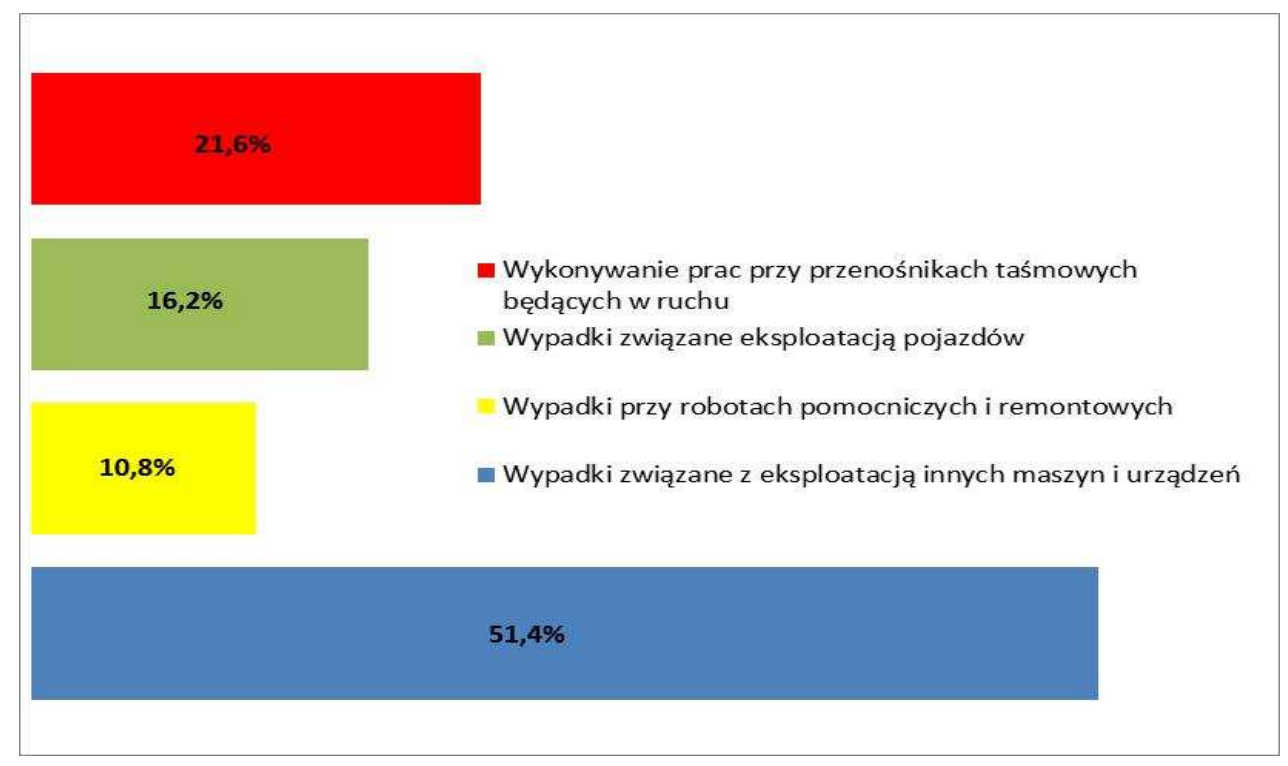

Rys. 5. Procentowy udział wypadków związany z zagrożeniami od maszyn i urządzeń w latach 20002016

Źródło: opracowanie własne na podstawie: Bezpieczeństwo pracy w kopalniach odkrywkowych i otworowych, WUG, Katowice 2014 oraz danych WUG (2003-2016)

\section{Zagrożenia pożarowe}

W latach 2000-2016 zarejestrowano 21 pożarów egzogennych w kopalniach odkrywkowych. Na szczęście zdarzenia te nie spowodowały urazów pracowników, jednak spowodowały straty spowodowane zniszczeniem maszyn i urządzeń, tj. koparek, zwałowarek, samochodów, taśm przenośników taśmowych, kabli elektrycznych. W KWB „Konin” nastą- 
piło zapalenie węgla brunatnego na skutek tarcia łańcucha koparki o płaszcz rolki podtrzymującej zablokowanej przez zalegający na wysięgniku urobek. Najwięcej pożarów zaistniało w roku 2012 (4) i w 2003 (3).

\section{WPLYW ZAGROŻEŃ NATURALNYCH I TECHNICZNYCH NA STAN BEZPIECZEŃSTWA PRACY}

\subsection{Zdarzenia niebezpieczne}

Zagrożenia naturalne i techniczne występujące w kopalniach odkrywkowych powodują liczne niebezpieczne zdarzenia, w wyniku których dochodzi do wypadków, w tym wypadków śmiertelnych. Zestawienie liczby niebezpiecznych zdarzeń wywołanych zagrożeniami naturalnymi i technicznymi w latach 2000-2016 przedstawiono w tabeli 1.

Tabela 1. Niebezpieczne zdarzenia wywołane zagrożeniami naturalnymi i technicznymi w latach 2000-2016

\begin{tabular}{|c|c|c|c|c|c|c|c|c|}
\hline Rok & Osuwiskowe & $\begin{array}{c}\text { Oberwanie } \\
\text { się skat }\end{array}$ & $\begin{array}{c}\text { Pożary } \\
\text { endo- } \\
\text { geniczne }\end{array}$ & $\begin{array}{c}\text { Razem } \\
\text { naturalne }\end{array}$ & Strzałowe & $\begin{array}{c}\text { Od maszyn } \\
\text { i urządzeń }\end{array}$ & $\begin{array}{c}\text { Pożary egzo- } \\
\text { geniczne }\end{array}$ & $\begin{array}{c}\text { Razem } \\
\text { techniczne }\end{array}$ \\
\hline 2000 & 2 & 1 & 0 & $\mathbf{3}$ & 0 & 0 & 0 & $\mathbf{0}$ \\
\hline 2001 & 0 & 0 & 0 & $\mathbf{0}$ & 1 & 1 & 1 & $\mathbf{3}$ \\
\hline 2002 & 4 & 1 & 0 & $\mathbf{5}$ & 0 & 3 & 1 & $\mathbf{4}$ \\
\hline 2003 & 0 & 0 & 0 & $\mathbf{0}$ & 0 & 0 & 3 & $\mathbf{3}$ \\
\hline 2004 & 3 & 0 & 0 & $\mathbf{3}$ & 0 & 4 & 1 & $\mathbf{5}$ \\
\hline 2005 & 2 & 0 & 1 & $\mathbf{3}$ & 0 & 4 & 0 & $\mathbf{4}$ \\
\hline 2006 & 1 & 0 & 0 & $\mathbf{1}$ & 0 & 0 & 0 & $\mathbf{0}$ \\
\hline 2007 & 2 & 1 & 0 & $\mathbf{3}$ & 0 & 2 & 0 & $\mathbf{2}$ \\
\hline 2008 & 1 & 1 & 0 & $\mathbf{2}$ & 0 & 4 & 1 & $\mathbf{5}$ \\
\hline 2009 & 0 & 0 & 0 & $\mathbf{0}$ & 0 & 3 & 1 & $\mathbf{4}$ \\
\hline 2010 & 2 & 2 & 0 & $\mathbf{4}$ & 3 & 0 & 2 & $\mathbf{5}$ \\
\hline 2011 & 2 & 2 & 1 & $\mathbf{5}$ & 0 & 5 & 2 & $\mathbf{7}$ \\
\hline 2012 & 0 & 0 & 0 & $\mathbf{0}$ & 0 & 0 & 4 & $\mathbf{4}$ \\
\hline 2013 & 2 & 0 & 0 & $\mathbf{2}$ & 1 & 0 & 1 & $\mathbf{2}$ \\
\hline 2014 & 0 & 0 & 0 & $\mathbf{0}$ & 1 & 7 & 1 & $\mathbf{9}$ \\
\hline 2015 & 0 & 1 & 0 & $\mathbf{1}$ & 0 & 4 & 2 & $\mathbf{6}$ \\
\hline 2016 & 0 & 0 & 0 & $\mathbf{0}$ & 2 & 0 & 1 & $\mathbf{3}$ \\
\hline Razem & $\mathbf{2 1}$ & $\mathbf{9}$ & $\mathbf{2}$ & $\mathbf{3 2}$ & $\mathbf{8}$ & $\mathbf{3 7}$ & $\mathbf{2 1}$ & $\mathbf{6 6}$ \\
\hline
\end{tabular}

Źródło: opracowanie własne na podstawie: Zagrożenia naturalne w odkrywkowych zakładach górniczych, WUG, Katowice 2007; Bezpieczeństwo pracy w kopalniach odkrywkowych i otworowych, WUG, Katowice 2014 oraz danych WUG (2003-2016)

W latach 2000-2016 wystąpiły 32 zdarzenia związane z występowaniem zagrożeń naturalnych, z czego 65,6\% stanowiły zagrożenia osuwiskowe, 28,1\% spowodowane obrywaniem się skał i $6,3 \%$ spowodowane powstaniem pożarów endogenicznych. Najwięcej niebezpiecznych zdarzeń zanotowano w 2002 (5), 2010 (4) oraz 2011 (5) roku (rys. 6). $\mathrm{W}$ ostatnich trzech latach zanotowano tylko jedno niebezpieczne zdarzenie związanych z zagrożeniami naturalnymi. 


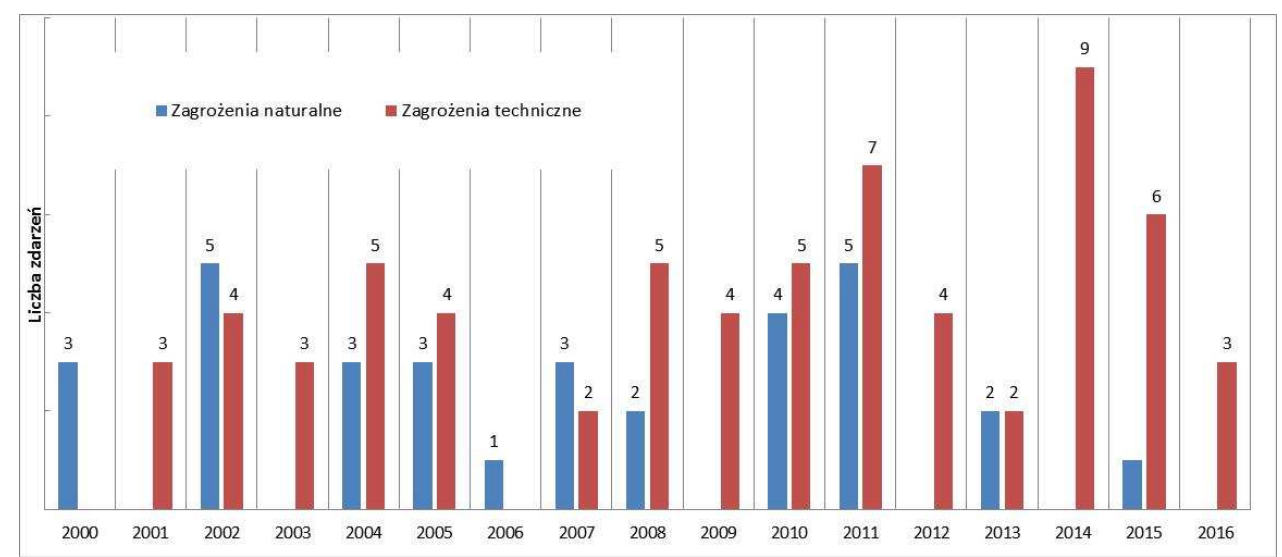

Rys. 6. Zdarzenia wywołane zagrożeniami naturalnymi i technicznymi w latach 2000-2016 Źródło: jak przy tabeli 1.

W latach 2000-2016 wystąpiło 66 niebezpiecznych zdarzeń związanych z występowaniem zagrożeń technicznych, z czego 56,1\% spowodowanych było zdarzeniami pochodzącymi od maszyn i urządzeń, 31,8\% stanowiły zdarzenia spowodowane powstaniem pożarów egzogenicznych i ponad $12 \%$ związanych było ze stosowaniem środków strzałowych. W 2014 roku wystąpiło 9 zdarzeń związanych z zagrożeniami technicznymi, w tym 7 pochodzących od maszyn i urządzeń.

\subsection{Wypadki śmiertelne spowodowane zagrożeniami naturalnymi i technicznymi}

Skalę wypadków śmiertelnych spowodowanych poszczególnymi zagrożeniami naturalnymi i technicznymi w odkrywkowych zakładach górniczych zaprezentowano w tabeli 2 oraz na rys. 7.

W latach 2000-2016 w całym górnictwie odkrywkowym zaistniały 4 wypadki śmiertelne bezpośrednio spowodowane zagrożeniami naturalnymi. 3 wypadki spowodowane były oberwaniem się skał na pracujących górników, 1 wypadek spowodowany był opadającymi masami skalnymi w zapadlisko na terenie Zakładu Górniczego Tomaszowskich Kopalń Surowców Mineralnych „Biała Góra”. W analizowanym okresie nie zaistniały wypadki spowodowane zdarzeniami związanymi z pożarami endogenicznymi.

W badanym okresie wystąpiło 20 wypadków śmiertelnych wywołanych zdarzeniami związanymi z zagrożeniami technicznymi. Pod względem liczby wypadków śmiertelnych za najpoważniejsze należy uznać zagrożenia techniczne od maszyn i urządzeń. Liczba wypadków śmiertelnych w omawianym okresie wyniosła 19, co stanowi 95\% wszystkich wypadków śmiertelnych pochodzących od zagrożeń technicznych.

W analizowanym okresie wystąpił 1 wypadek śmiertelny spowodowany detonacją materiałów wybuchowych w Kopalni Wapienia „Morawica”. Najwięcej wypadków śmiertelnych od maszyn i urządzeń zanotowano w 2003 (3), 2011 (3) oraz 2015 (3) roku. Mimo że pod względem liczby niebezpiecznych zdarzeń spowodowanych zagrożeniami technicznymi częstymi zdarzeniami są pożary egzogeniczne, to w analizowanym okresie nie spowodowały one wypadków śmiertelnych. 
Tabela 2. Wypadki śmiertelne w wyniku zagrożeń naturalnych i technicznych w latach 2000-2016

\begin{tabular}{|c|c|c|c|c|c|c|c|c|}
\hline Rok & Osuwiskowe & $\begin{array}{c}\text { Oberwanie } \\
\text { się skał }\end{array}$ & $\begin{array}{c}\text { Pożary } \\
\text { endo- } \\
\text { geniczne }\end{array}$ & $\begin{array}{c}\text { Razem } \\
\text { naturalne }\end{array}$ & Strzałowe & $\begin{array}{c}\text { Od ma- } \\
\text { szyn i } \\
\text { urządzeń }\end{array}$ & $\begin{array}{c}\text { Pożary egzo- } \\
\text { geniczne }\end{array}$ & $\begin{array}{c}\text { Razem } \\
\text { techniczne }\end{array}$ \\
\hline 2000 & 0 & 1 & 0 & $\mathbf{1}$ & 0 & 0 & 0 & $\mathbf{0}$ \\
\hline 2001 & 0 & 0 & 0 & $\mathbf{0}$ & 1 & 1 & 0 & $\mathbf{2}$ \\
\hline 2002 & 0 & 0 & 0 & $\mathbf{0}$ & 0 & 2 & 0 & $\mathbf{2}$ \\
\hline 2003 & 0 & 0 & 0 & $\mathbf{0}$ & 0 & 0 & 0 & $\mathbf{0}$ \\
\hline 2004 & 0 & 0 & 0 & $\mathbf{0}$ & 0 & 3 & 0 & $\mathbf{3}$ \\
\hline 2005 & 0 & 0 & 0 & $\mathbf{0}$ & 0 & 2 & 0 & $\mathbf{2}$ \\
\hline 2006 & 0 & 0 & 0 & $\mathbf{0}$ & 0 & 0 & 0 & $\mathbf{0}$ \\
\hline 2007 & 0 & 0 & 0 & $\mathbf{0}$ & 0 & 0 & 0 & $\mathbf{0}$ \\
\hline 2008 & 0 & 0 & 0 & $\mathbf{0}$ & 0 & 1 & 0 & $\mathbf{1}$ \\
\hline 2009 & 0 & 0 & 0 & $\mathbf{0}$ & 0 & 2 & 0 & $\mathbf{2}$ \\
\hline 2010 & 0 & 1 & 0 & $\mathbf{1}$ & 0 & 0 & 0 & $\mathbf{0}$ \\
\hline 2011 & 1 & 0 & 0 & $\mathbf{1}$ & 0 & 3 & 0 & $\mathbf{3}$ \\
\hline 2012 & 0 & 0 & 0 & $\mathbf{0}$ & 0 & 0 & 0 & $\mathbf{0}$ \\
\hline 2013 & 0 & 0 & 0 & $\mathbf{0}$ & 0 & 0 & 0 & $\mathbf{0}$ \\
\hline 2014 & 0 & 0 & 0 & $\mathbf{0}$ & 0 & 2 & 0 & $\mathbf{2}$ \\
\hline 2015 & 0 & 1 & 0 & $\mathbf{1}$ & 0 & 3 & 0 & $\mathbf{3}$ \\
\hline 2016 & 0 & 0 & 0 & $\mathbf{0}$ & 0 & 0 & 0 & $\mathbf{0}$ \\
\hline Razem & $\mathbf{1}$ & $\mathbf{3}$ & $\mathbf{0}$ & $\mathbf{4}$ & $\mathbf{1}$ & $\mathbf{1 9}$ & $\mathbf{0}$ & $\mathbf{2 0}$ \\
\hline
\end{tabular}

Źródło: jak przy tabeli 1.

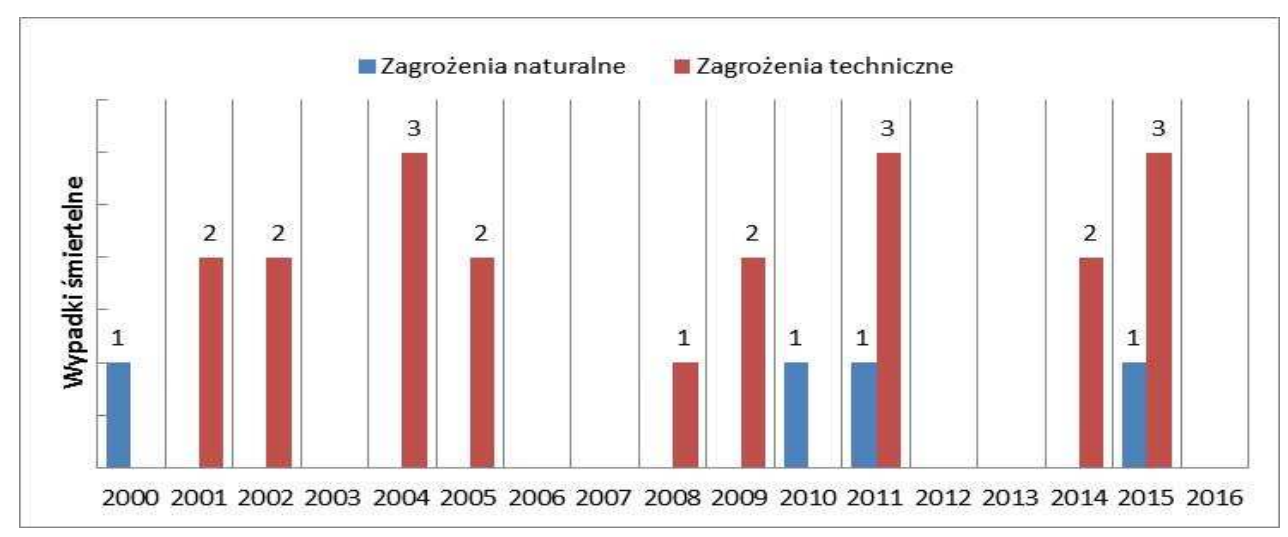

Rys. 7. Wypadki śmiertelne wywołane zagrożeniami naturalnymi i technicznymi w latach 2000-2016 Źródło: jak przy tabeli 1. 


\subsection{Zagrożenia naturalne i techniczne a ogólna wypadkowość śmiertelna}

Skalę wypadków śmiertelnych spowodowanych zagrożeniami naturalnymi i technicznymi na tle wszystkich wypadków śmiertelnych w latach 2002-2016 przedstawia tabela 3.

Największy udział zagrożeń naturalnych w wypadkach śmiertelnych zanotowano w roku: $2010(50 \%), 2011(20 \%)$ i 2015 (25\%), kiedy wystąpiły zdarzenia związane z oberwaniem się skał oraz osuwiskiem w kopalniach odkrywkowych. Ogólny udział zagrożeń naturalnych we wszystkich wypadkach śmiertelnych w badanym okresie wynosi 7,3\%.

W roku 2004, 2005 i 2009 wszystkie zaistniałe wypadki śmiertelne w górnictwie odkrywkowym były wypadkami spowodowanymi zagrożeniami technicznymi. Wysoki udział tych wypadków miał również miejsce w roku: 2002 (66,7\%), 2008 (50\%), 2011 (60\%), $2014(50 \%)$ i 2015 (75\%). Ogólny udział zagrożeń technicznych we wszystkich wypadkach śmiertelnych w analizowanym okresie wynosi blisko $44 \%$.

Tabela 3. Skala wypadków śmiertelnych spowodowanych zagrożeniami naturalnymi i technicznymi na tle wszystkich wypadków śmiertelnych w latach 2002-2016

\begin{tabular}{|c|c|c|c|c|c|}
\hline Rok & $\begin{array}{l}\text { Wszystkie } \\
\text { wypadki } \\
\text { śmiertelne }\end{array}$ & $\begin{array}{c}\text { Wypadki } \\
\text { z zagrożeń } \\
\text { naturalnych }\end{array}$ & $\begin{array}{l}\text { Udział wypad- } \\
\text { ków z zagrożeń } \\
\text { naturalnych } \\
\text { w [\%] }\end{array}$ & $\begin{array}{c}\text { Wypadki } \\
\text { z zagrożeń } \\
\text { technicznych }\end{array}$ & $\begin{array}{c}\text { Udział wypad- } \\
\text { ków z zagrożeń } \\
\text { technicznych } \\
\text { w [\%] }\end{array}$ \\
\hline 2002 & 3 & 0 & 0 & 2 & 66,7 \\
\hline 2003 & 3 & 0 & $\mathbf{0}$ & 0 & $\mathbf{0}$ \\
\hline 2004 & 3 & 0 & $\mathbf{0}$ & 3 & 100 \\
\hline 2005 & 2 & 0 & $\mathbf{0}$ & 2 & 100 \\
\hline 2006 & 0 & 0 & $\mathbf{0}$ & 0 & $\mathbf{0}$ \\
\hline 2007 & 5 & 0 & 0 & 0 & 0 \\
\hline 2008 & 2 & 0 & 0 & 1 & 50 \\
\hline 2009 & 2 & 0 & 0 & 2 & 100 \\
\hline 2010 & 2 & 1 & 50 & 0 & 0 \\
\hline 2011 & 5 & 1 & 20 & 3 & 60 \\
\hline 2012 & 2 & 0 & 0 & 0 & 0 \\
\hline 2013 & 4 & 0 & 0 & 0 & $\mathbf{0}$ \\
\hline 2014 & 4 & 0 & 0 & 2 & 50 \\
\hline 2015 & 4 & 1 & 25 & 3 & 75 \\
\hline 2016 & 0 & 0 & 0 & 0 & 0 \\
\hline Razem & 41 & 3 & 7,3 & 18 & 43,9 \\
\hline
\end{tabular}

Źródło: opracowanie własne.

\subsection{Wypadkowość śmiertelna a liczba zatrudnionych}

Prowadząc analizę wypadkowości w górnictwie nie można pominąć wskaźnika częstości wypadków śmiertelnych w przeliczeniu na 1000 zatrudnionych. Wartość omawianego wskaźnika w odniesieniu do wszystkich wypadków śmiertelnych oraz wypadków wynikających z zagrożeń naturalnych i technicznych przedstawiono w tabeli 4. Wartość wskaźnika w odniesieniu do zagrożeń technicznych ilustruje rys. 8. 
Tabela 4. Wskaźnik częstości wypadków śmiertelnych na 1000 zatrudnionych w latach 2002-2016

\begin{tabular}{|c|c|c|c|c|c|c|c|}
\hline Rok & $\begin{array}{c}\text { Wszystkie wy- } \\
\text { padki } \\
\text { śmiertelne } \\
{[-/ 1000 \text { za- }} \\
\text { trud.] }\end{array}$ & $\begin{array}{c}\text { Wypadki } \\
\text { z zagrożeń } \\
\text { naturalnych } \\
{[-/ 1000 \text { za- }} \\
\text { trud.] }\end{array}$ & $\begin{array}{c}\text { Wypadki } \\
\text { z zagrożeń } \\
\text { technicznych } \\
{[-/ 1000 \text { za- }} \\
\text { trud.] }\end{array}$ & Rok & $\begin{array}{c}\text { Wszystkie wy- } \\
\text { padki } \\
\text { smiertelne } \\
{[-/ 1000 \text { za- }} \\
\text { trud.] }\end{array}$ & $\begin{array}{c}\text { Wypadki } \\
\text { z zagrożeń } \\
\text { naturalnych } \\
{[-/ 1000 \text { za- }} \\
\text { trud.] }\end{array}$ & $\begin{array}{c}\text { Wypadki } \\
\text { z zagrożeń } \\
\text { technicznych } \\
{[-/ 1000 \text { za- }} \\
\text { trud.] }\end{array}$ \\
\hline 2002 & 0,08 & 0,00 & 0,06 & 2009 & 0,07 & 0,00 & 0,07 \\
\hline 2003 & 0,10 & 0,00 & 0,00 & 2010 & 0,06 & 0,03 & 0,00 \\
\hline 2004 & 0,10 & 0,00 & 0,10 & 2011 & 0,16 & 0,03 & 0,09 \\
\hline 2005 & 0,06 & 0,00 & 0,06 & 2012 & 0,06 & 0,00 & 0,00 \\
\hline 2006 & 0,00 & 0,00 & 0,00 & 2013 & 0,14 & 0,00 & 0,00 \\
\hline 2007 & 0,16 & 0,00 & 0,00 & 2014 & 0,15 & 0,00 & 0,07 \\
\hline 2008 & 0,06 & 0,00 & 0,03 & 2015 & 0,14 & 0,04 & 0,11 \\
\hline Średnia & & & $\mathbf{0 , 0 9}$ & $\mathbf{0 , 0 1}$ & $\mathbf{0 , 0 4}$ \\
\hline
\end{tabular}

Źródło: opracowanie własne

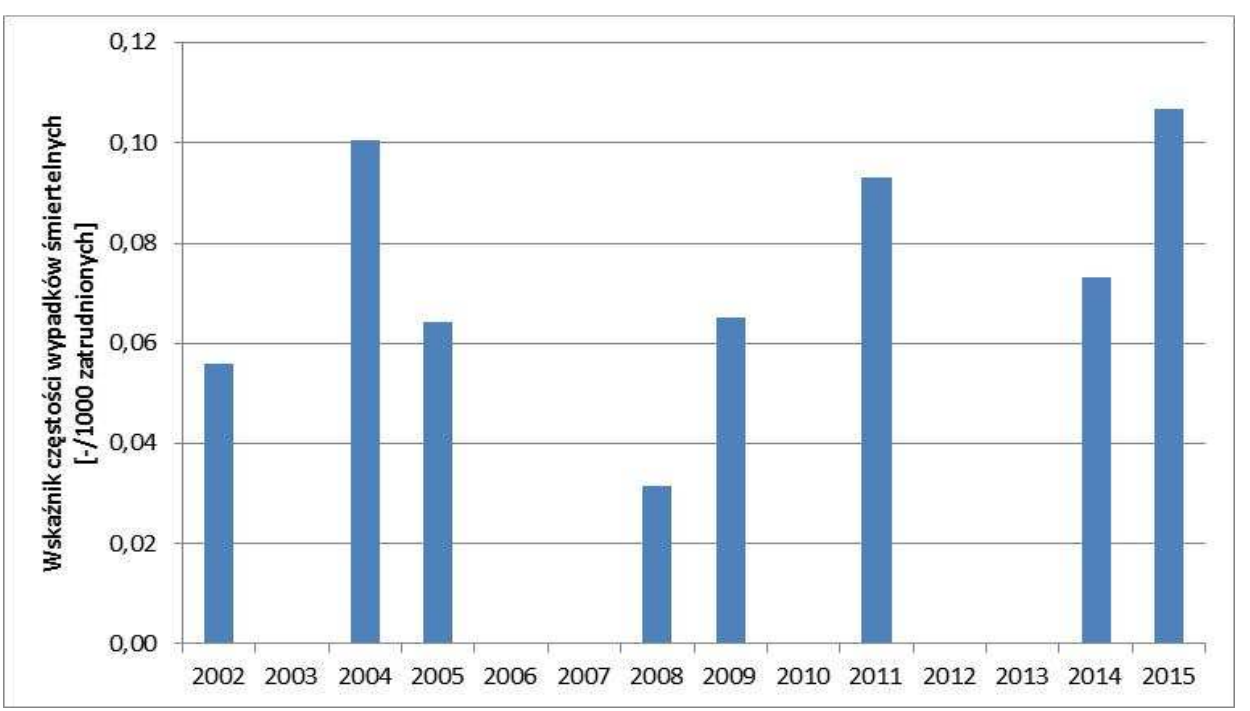

Rys. 8. Wskaźnik częstości wypadków śmiertelnych spowodowanych zagrożeniami technicznymi na 1000 zatrudnionych w latach 2002-2015

Źródło: opracowanie własne.

W latach 2002-2015 wskaźnik częstości wszystkich wypadków śmiertelnych wyniósł 0,09, przy czym najwyższe wartości tego wskaźnika miały miejsce w roku $2007(0,16)$, $2011(0,16)$ i $2014(0,15)$. Z uwagi na stosunkowo niewielką liczbę wypadków śmiertelnych spowodowanych zdarzeniami wynikającymi z zagrożeń naturalnych w stosunku do wszystkich wypadków śmiertelnych, wskaźnik częstości został obliczony dla roku $2010(0,03)$, 
$2011(0,03)$ oraz $2015(0,04)$. Najwyższe wartości wskaźnika częstości wypadków śmiertelnych spowodowanych zdarzeniami od zagrożeń technicznych miały miejsce w roku 2015 $(0,11), 2004(0,10)$ i $2011(0,9)$, a dla całego badanego okresu wskaźnik ten wyniósł 0,04.

\section{ZAKOŃCZENIE}

Górnictwo odkrywkowe jest najstarszym sposobem wydobywania kopalin, dzięki którym możliwy jest rozwój cywilizacyjny. Od początku jego istnienia praca górników związana była z licznymi niebezpieczeństwami, które zagrażały ich życiu i zdrowiu. Eksploatacji prowadzonej w kopalniach odkrywkowych towarzyszą liczne zagrożenia naturalne, techniczne i osobowe. Podstawowymi zagrożeniami naturalnymi są zagrożenia osuwiskowe, wywołane obrywaniem się skał, wodne, sejsmiczne, gazowe, wywołane pożarami endogenicznymi i inne związane z budową geologiczną złoża i nadkładu. Do zagrożeń technicznych można zaliczyć zagrożenia od maszyn i urządzeń, związane ze stosowaniem środków strzałowych oraz zagrożenia pożarami egzogenicznymi.

Na podstawie przeprowadzonej analizy danych pochodzących z Wyższego Urzędu Górniczego dotyczących stanu bezpieczeństwa w polskich kopalniach można wysunąc następujące wnioski:

1. W ciągu ostatnich 15 lat liczba odkrywkowych zakładów górniczych uległa podwojeniu. Głównie są to zakłady o małym wydobyciu (do $0,1 \mathrm{mln}$ t/rok) i średnim wydobyciu (od 0,1-1,0 mln t/rok).

2. W omawianym okresie pomimo znaczącego wzrostu liczby funkcjonujących odkrywkowych zakładów górniczych, nastąpił spadek zatrudnienia w całym górnictwie odkrywkowym o $21 \%$. Główną przyczyną była restrukturyzacja zatrudnienia w kopalniach węgla brunatnego.

3. Liczba wypadków w kopalniach odkrywkowych w okresie 2002-2015 znacząco uległa zmniejszeniu z 119 do 58, co stanowi spadek o ponad $51 \%$. W badanym okresie wartość wskaźnika częstości wypadków również malała, z 3,33 w roku 2002 do 2,06 w roku 2015. Oznacza to, że spadek liczby wypadków jest spowodowany nie tylko mniejszą liczbą zatrudnionych, ale również ogólną poprawą stanu bezpieczeństwa w polskim górnictwie odkrywkowym.

4. W latach 2000-2016 wystąpiły 32 zdarzenia związane z występowaniem zagrożeń naturalnych oraz 66 zdarzeń związanych z występowaniem zagrożeń technicznych. Największy udział w powyższych zagrożeniach miały odpowiednio: zdarzenia związane z zagrożeniem osuwiskowym i zdarzenia związane z zagrożeniami występującymi od maszyn i urządzeń.

5. Wypadki śmiertelne spowodowane zdarzeniami związanymi z zagrożeniami naturalnymi w odniesieniu do wszystkich wypadków śmiertelnych mających miejsce w kopalniach odkrywkowych stanowią stosunkowo mały udział 7,3\%. Znacznie większy udział wynoszący blisko $44 \%$ mają wypadki spowodowane zdarzeniami związanymi z zagrożeniami technicznymi. W roku 2004, 2005 i 2009 udział ten był 100-procentowy.

6. Zagrożenia techniczne mają znaczący wpływ na stan bezpieczeństwa pracy w polskich kopalniach odkrywkowych. W mniejszej skali mają je również zagrożenia naturalne, w wyniku których może wystąpić konieczność przerwania prowadzonej eksploatacji, a tym samym zmniejszenia zdolności wydobywczych kopalń. 


\section{LITERATURA}

[1] Bezpieczeństwo pracy w kopalniach odkrywkowych i otworowych, WUG, Katowice 2014.

[2] Ciechowski E., Szczurowski A., Seminarium z bezpieczeństwa i higieny pracy w górnictwie, Politechnika Śląska, Gliwice 1996.

[3] Ocena stanu bezpieczeństwa pracy, ratownictwa górniczego oraz bezpieczeństwa powszechnego w związku z działalnościa górniczo-geologiczna w 2013 roku, WUG, Katowice 2014.

[4] Ocena stanu bezpieczeństwa pracy, ratownictwa górniczego oraz bezpieczeństwa powszechnego w zwiazku z działalnościa górniczo-geologiczna w 2014 roku, WUG, Katowice 2015.

[5] Ocena stanu bezpieczeństwa pracy, ratownictwa górniczego oraz bezpieczeństwa powszechnego w związku z działalnościa górniczo-geologiczna w 2015 roku, WUG, Katowice 2016.

[6] Rozporządzenie Ministra Środowiska z dnia 29 stycznia 2013 r. w sprawie zagrożeń naturalnych w zakładach górniczych (tekst jedn. Dz.U. z 2015 r. poz. 1702).

[7] Stan bezpieczeństwa i higieny pracy w górnictwie w 2002 roku, WUG, Katowice 2003.

[8] Stan bezpieczeństwa i higieny pracy w górnictwie w 2003roku, WUG, Katowice 2004.

[9] Stan bezpieczeństwa i higieny pracy w górnictwie w 2004 roku, WUG, Katowice 2005.

[10] Stan bezpieczeństwa i higieny pracy w górnictwie w 2005 roku, WUG, Katowice 2006.

[11] Stan bezpieczeństwa i higieny pracy w górnictwie w 2006 roku, WUG, Katowice 2007.

[12] Stan bezpieczeństwa i higieny pracy w górnictwie w 2007 roku, WUG, Katowice 2008.

[13] Stan bezpieczeństwa i higieny pracy w górnictwie w 2008 roku, WUG, Katowice 2009.

[14] Stan bezpieczeństwa i higieny pracy w górnictwie w 2009 roku, WUG, Katowice 2010.

[15] Stan bezpieczeństwa i higieny pracy w górnictwie w 2010 roku, WUG, Katowice 2011.

[16] Stan bezpieczeństwa i higieny pracy w górnictwie w 2011 roku, WUG, Katowice 2012.

[17] Stan bezpieczeństwa i higieny pracy w górnictwie w 2012 roku, WUG, Katowice 2013.

[18] J. Szlązak J., Szlązak N., Bezpieczeństwo i higiena pracy, Wydawnictwo AGH, Kraków 2005.

[19] Ustawa z dnia 9 czerwca 2011 r. Prawo geologiczne i górnicze (tekst jedn. Dz.U. z 2016 r., poz. 1131).

[20] Zagrożenia naturalne w odkrywkowych zakładach górniczych, WUG, Katowice 2007.

\section{NATURAL AND TECHNICAL HAZARDS AFFECTING THE STATUS OF SAFETY IN THE POLISH OPEN-PIT MINES}

Open-pit mining is the oldest way of extracting useful minerals that have been used by humans for thousands of years. Today, opencast mining is the basic branch of many countries' economies, including developed countries. It allows to source energy, metallic, chemical and rock resources. In Poland in recent years the dynamic development of the opencast mining industry has been observed. In the last 15 years, the number of open-cast mining plants has doubled. Since the beginning of mining, the work of miners has been associated with many dangers that threatened their lives and health. Basic hazards affecting work safety in open-pit mines include geological, geotechnical and hydrogeological hazards, as well as technical hazards associated with the use of certain technologies for the extraction and processing of raw materials, machinery, equipment and means of transport.

The article describes the definition of the open-pit mine, the distribution of mines due to the economic use of minerals and the employment status of mines. The basic hazards occurring at workplaces in opencast mining are also described. To perform the analysis of accidents, data and reports collected by the State Mining Authority (SMA) were used. Special attention 
was paid to events related to natural and technical hazards in open pit mines. It has been characterized and described the scale of existing hazards: landslide, collapsing rocks, water, seismic, gas, endogenous fire and technical from machines and equipment, and associated with the use of explosive.

Keywords: natural hazards, technical hazards, open-pit mining, work safety in mining.

\section{DOI: 10.7862/rz.2017.mmr.19}

Tekst złożono w redakcji: maj 2017 r.

Przyjęto do druku: czerwiec 2017 r. 
